\title{
Conservative Anti-Colonialism: Maududi, Marx and
}

\section{Social Equality ${ }^{1}$}

HUMEIRA IQTIDAR

\begin{abstract}
Abul A 'la Maududi explicitly built on Islamic ideas of equality to critique nationalism and modern racism. How then could he reject the idea of social equality between men and women? This is particularly puzzling given his noticeable employment of a Marxist critique of the marketisation of society and liberal conceptions of freedom in his controversial 1939 book Pardah. Parsing out the structure of his argument in Pardah in some detail and emphasising the hitherto understudied engagement with Marxist ideas in his thought, this article shows that Maududi rejected a specific vision of social equality, where equality amounts to exchangeability. His use of Marxist ideas to non-Marxist ends was in large part a result of his assessment of Marx as a capable historian but a flawed philosopher, and more fundamentally a very different conception of society to the Marxist one. Maududi relied on his by then well-developed concept of divine sovereignty to carry much of the conceptual burden regarding his critique of, as well as alternatives to, social equality.
\end{abstract}

Keywords: Anti-colonial thought; Abul A'la Maududi; social equality; Marxism in South Asia

Abul A'la Maududi (1903-I9) can rightly be seen as a foundational theorist of the influential new concept, hakimiyyat ${ }^{2}$ or divine sovereignty. Concerned with working through the implications of the idea of popular sovereignty that enthused many anti-colonial movements at the same time as reckoning with the institutional reality of the modern state, ${ }^{3}$ Maududi articulated a detailed vision of what it would mean to recognise the political sovereignty of Allah. This was a creative intervention that reworked existing but differently inflected ideas in the Islamic tradition about Allah's ownership of the cosmos as Muhammad

${ }^{1}$ I am grateful to Sanjay Seth, Muhammad Qasim Zaman and Oliver Scharbrodt for their incisive and critical comments. Sarah Ansari has provided thoughtful guidance and support, which has been immensely valuable.

${ }^{2}$ Maududi wrote in Urdu, and here I use the Urdu word that Maududi used rather than the Arabic version hakimiyya.

${ }^{3}$ Humeira Iqtidar, 'Theorising Popular Sovereignty in the Colony: Abul A'la Maududi’s "Theodemocracy"', The Review of Politics 82, 4 (Autumn, 2020), pp. 595-6I 7. article, distributed under the terms of the Creative Commons Attribution-NonCommercial-NoDerivatives licence (http://creative commons.org/licenses/by-nc-nd/4.0/), which permits non-commercial re-use, distribution, and reproduction in any medium, provided the original work is unaltered and is properly cited. The written permission of Cambridge University Press must be obtained for commercial re-use or in order to create a derivative work. 
Qasim Zaman has persuasively argued. ${ }^{4}$ Moreover, Maududi was immensely resourceful in bringing together ideas from across traditions, engaging both European and Islamic thought. That he was coining a new reading of the term needing some translation is evident from the fact that he had to include the English word sovereignty in brackets next to the term hakimiyyat when he first used it. ${ }^{5}$ Part of the reason why Maududi's formulation was so influential was that he was a systematic thinker who worked through the implications of divine sovereignty not just for the modern state but also for social life.

One important manifestation of Maududi's philosophical critique of popular sovereignty was his opposition to the idea of social equality, which he saw as promoting exchangeability and sameness. Popular sovereignty, he thought, constructs the facade of voting individuals as equal and free despite the many differences in their actual life. ${ }^{6}$ These erasures of actual difference both rest on and promote the idea that ultimately all humans are the same. Maududi disagreed. He thought that while the potential for spiritual equality existed for all humans, and legal equality or equality before law was mandated by the shari'a, social equality was a mirage that would rip communities apart through atomisation and individualisation. His opposition to social equality, especially gender equality, is particularly striking given his heavy reliance on Marxist critiques of capitalist democracy. Some scholarship has noted Maududi's opposition to Marxist ideas. ${ }^{7}$ However, Maududi's actual engagement with Marxist ideas that had begun to dominate the anti-colonial movement has not been explored closely. Here I highlight some contours of Global South Marxist thought and practice by working through both the spheres of agreement and disagreement in Maududi's engagement with it.

Prior to writing Pardah, ${ }^{8}$ Maududi had started developing a detailed critique of the philosophical underpinnings of nationalism. He saw nationalism as a European invention that went beyond the love for one's quom or watan. ${ }^{9}$ One important concern was that nationalism

${ }^{4}$ Muhammad Qasim Zaman, 'The Sovereignty of God in Modern Islamic Thought', Journal of Royal Asiatic Society 25, 3 (2015), p. 405. See also Al-Azmi this volume for a differently inflected reading.

${ }^{5}$ Abul A'la Maududi, Islām ka nazariya siyāsi (Bareilly, n.d.), I2. See also Ebrahim Moosa, 'Shari'at Governance in Colonial and Postcolonial India', in Islam in South Asia in Practice, (ed.) Barbara Metcalf (Princeton, 2009), pp. 317-325, for an earlier discussion of ideas about the notion of divine governance that were not yet fully articulated in the direction that Maududi took them.

${ }^{6}$ These strains were felt historically in multiple ways. David Gilmartin ('Towards a Global History of Voting: Sovereignty, the Diffusion of Ideas, and the Enchanted Individual', Religions 3 (2OI2), p. 4I2) has perceptively noted a fundamental tension in the idea of popular sovereignty that played itself out in debates regarding the secret ballot: “...it was the individual voter who embodied both sides of this equation, a man of the world defined by his sociology, his objectifiable class, identity and interests, and a man imagined at the very same time to be endowed with a freedom of will that put him beyond sociology, and thus capable of exercising autonomy".

${ }^{7}$ Notably Jan-Peter Hartung, A System of Life, Mawdudi and the ideologisation of Islam (London, 2014), pp. 49, I34-I36; S. V. R. Nasr, Mawdudi and The Making of Islamic Revivalism (Oxford, I996), pp. I5, 25, I05; Humeira Iqtidar, Secularizing Islamists? Jamaat-e-Islami and Jamaat-ud-Dawa in Urban Pakistan (Chicago, 20 I I), pp. 58-65.

${ }^{8}$ The term pardah is used most widely in the South Asian context and applies to a range of practices followed by both Muslim and some Hindu communities. While the term literally translates as 'curtain', it includes different practices such as varying degrees of segregation between men and women, etiquette of interaction and modest clothing. The specific combinations and intensity vary significantly across classes and regions (Hanna Papanek, 'Separate Worlds and Symbolic Shelter', Comparative Studies in Society and History I5, 3 (June I973), pp. 289$325)$. On the whole, it seems that lower- and working-class women have better mobility with lower requirements for pardah, but upper-class women tend to have more space and resources to fill their segregated spaces with ceremonies and education. See Shaista Ikramullah, Behind the Veil (Karachi, n.d.) and, for working-class Punjabi women, Tehmina Rashid, Contested representation: Punjabi women in feminist debate in Pakistan (Karachi, 2006).

${ }^{9}$ Radha D'Souza ('The conceptual world of the Ghaddarites', Socialist Studies/Etudes socialistes I 3, 2 (Autumn, 20I8), p. 27) has provided a succinct translation of the two in late nineteenth- and early twentieth-century Indo-Islamic thought: "Quom' is a difficult word to translate into English. What is pertinent is that a quom is a 
promoted exclusion and oppression on the basis of race. This he argued was against the Islamic principle of equality. ${ }^{10}$ How could he, then, object to the idea of social equality between men and women? If equality was an Islamic principle, then what were the precise concerns that led him to proclaim that pardah was the "last pillar standing" of Islamic form of life and needed to be preserved? ${ }^{11}$ Here, I shall first expand upon Maududi's opposition to social equality as exchangeability that he articulated at some length in his influential and immediately controversial text Pardah published in 1939. This is the book that confirmed his status as a conservative thinker, and as a deeply anti-woman one. ${ }^{12}$ Through a close reading of his arguments I suggest that Maududi incorporates a Marxist analysis of colonial and capitalist expansion to critique the idea of social equality as exchangeability.

However, he drew very different conclusions from Marxists about what is to be done. This is in part because of a very different conception of society from that proposed by Marxists of his time. Maududi viewed society as a means to individual ethical perfection and his primary concern was with the moral laxity that flowed from the assumption that society could be fundamentally reorganised and 'man-made laws' could replace divine ones. If sovereignty belonged to God, as (he argued) all Muslims were bound to believe, then social arrangements could not be reworked to transcend the moral limits imposed by God. He claimed that he was proposing a middle ground between what he saw as the two extremes of liberal and Marxist ideas, and so recommended greater fidelity to and acceptance of divine sovereignty as part of the solution.

In foregrounding this engagement with Marxist ideas in Maududi's thought, my aim is not to suggest that Maududi was a Marxist, nor that he was a 'progressive' in the sense of supporting a left/liberal emancipatory programme, or a nationalist one. However, he was against colonialism and saw much potential for improvement in traditional norms. Anti-colonial thought and activism has been profoundly associated with nationalism and progressive politics, and not just in South Asian scholarship. The depth of the assumed relationship between progressive politics and anti-colonialism is such that even when nationalism became a tainted ideology in Europe after the excesses of the Nazi regime, anti-colonial nationalism in the global south continued to retain its positive connotations. ${ }^{13}$ Yet, there were many anti-colonial activists and thinkers, such as Gandhi and Maududi, who, despite many differences in their ideas, were both reluctant to endorse a clear left leaning

historically constituted community that may or may not be affiliated to territory. Watan, translated as 'homeland' denotes affinity to place of one or several quoms".

${ }^{10}$ This was articulated in detail in his early text Al Jihad fil Islam as well as later writings on nationalism, particularly Musalman aur Maujooda Syasi Kashmakash (Muslims and the Current Political Struggle, I938), and Masala-e-Qaumiyat (The Problem of Nationalism, 1939).

${ }^{11}$ Abul 'Ala Maududi, Pardah (Lahore, 2003 [1939]), p. 304.

${ }^{12}$ See, for instance, Irfan Ahmed, 'Cracks in the "Mightiest Fortress": Jamaat-e-Islami's Changing Discourse on Women', Modern Asian Studies 42, 2-3 (2008), pp. 549-575. Interestingly, when he started learning Arabic, one of the first books Maududi translated was a critique of pardah (Leonard Binder, Religion and Politics in Pakistan (California, I963), p.I04), most likely a book by the Egyptian reformer Qasim Amin.

${ }^{13}$ James Mayall, 'Nationalism and Imperialism', in, Cambridge History of Twentieth Century Political Thought, (eds.) Terrence Ball and Richard Bellamy (Cambridge, 2003), pp. i I8, I20; and more recently Adom Getachew World Making After Empire: The Rise and Fall of Self-Determination (Princeton, 2019). 
programme and were wary of the promise of social equality. ${ }^{14}$ Definitions of conservatism ${ }^{15}$ predicated on opposition to change, or support for existing power structures fail to capture the dynamics of their thought. Similarly, visions of progressiveness as being inextricable from anti-colonial critique limit our understanding of the range of possible political imaginaries. Rather than proposing that Maududi fits neatly within either camp, the attempt here is to highlight the limitations of this frame and to propose greater attention to parsing out the specific elements of Maududi's critique as a way of thinking more clearly about precise concerns regarding social equality.

\section{Women in a market society}

Willing to imagine a future moving towards progress, and a committed modernist, Maududi nevertheless contested gender social equality as imagined in Europe. While many Indian nationalists and modernists were also distrustful of European visions of women's equality, ${ }^{16}$ Maududi is unique to the extent that he makes a sustained, systematic and principled argument against them. Critically, he saw both communist and liberal visions of social equality as carrying the same implications. In his book Pardah he made a direct and explicit argument for the segregation of sexes with women placed clearly in the home, the moral authority of men over women, and ultimately, the impossibility of erasing social distinctions between the men and women. These distinctions he argued were part of a larger moral framework, the breakdown of which would be catastrophic in moral, spiritual and civilisational implications. Providing lurid details of 'moral degeneracy' and sexual anarchy in Europe that rivalled the visions orientalists painted of the harem, Maududi did not let any nuance stand in the way of making his point. Having never visited Europe Maududi relied on Euro-American authors to detail these changes in morality, ${ }^{17}$ to argue that this breakdown came with the idea that humans could reconfigure moral limits set by God to reorganise social structures completely.

In the case of Europe, he argued that the desire for social equality with men, expressed as an aspiration to do precisely everything that men could, was a reaction to the extreme

\footnotetext{
${ }^{14}$ See Uday Singh Mehta, 'Gandhi in Democracy, Politics and the Ethics of Everyday Life', Modern Intellectual History 7, 2 (20I0), pp. 355-37I; Dilip Menon, 'An Eminent Victorian: Gandhi, Hind Swaraj and the Crisis of Liberal Democracy in the Nineteenth Century', History of the Present 7, I (2017), pp. 33-58. In Gandhi's handling of the caste question in particular we see a refusal of equality as an ethical ideal and legal norm, see Arundhati Roy, The Saint and the Doctor: Caste, race and the annihilation of caste (Chicago, 2017).

${ }^{15}$ For the ongoing problem of defining conservatism in European political thought see Richard Bourke, 'What is conservatism: History, ideology and party', European Journal of Political Theory 17, 4 (2018), pp. 449-475.

${ }^{16}$ One important site for these discussions in late nineteenth and early twentieth century India was women's right to education. Here we see concerns about education leading to Westernization of Indian women being expressed by a range of thinkers and reformers such as Gandhi, Tagore, Lala Lajpat Rai, Ashraf Ali Thanwi, Sir Syed Ahmed and Sheikh Abdullah. See Sanjay Seth, Gender and the Nation: Debating female education in Subject Lesson: The Western education of colonial India (North Carolina, 2007), pp. I29-I58, and Shadab Bano, 'Reform and identity: Purdah in Muslim women's education in Aligarh in the early twentieth century', Proceedings of the Indian History Congress 73 (2012), pp. 607-6I4.

${ }^{17}$ Maududi drew upon a range of European critics of these changes in European morality. In an interesting contrast to many other important South Asian thinkers and political figures of South Asia of his time- Jinnah, Nehru, Gandhi, Ambedkar, Bose, the Ali Brothers, M. N. Roy and Tagore-Maududi had never visited Europe. He used books like Paul Bureau's Towards Moral Bankruptcy (English translation, I930), a lament for the world lost in the aftermath of the First World War, to provide him with an insight into contemporary European society, and others such as Edith Houghten Hooker's Laws of Sex (I92I), George Ryle Scott's A History of Prostitution from Antiquity to the Present Day (1936), and Ben B. Lindsey's Revolt of the Modern Youth (I924) to document transformations in morality in the European society.
} 
deprivation suffered by European women. Unthinking Indian followers of ideas and norms established for that context risked, he warned, tearing asunder their own social fabric. Maududi claimed that the two most complex yet critical questions for thinkers and scholars across time and cultures had remained the following: first, how to balance the relationship between men and women in collective life, and second, how to calibrate the relationship between the individual and the collective. ${ }^{18}$ To assess the first question and to assert that Europe presented a particularly unbalanced vision, Maududi undertook a survey of the relationship between men and women in European history: Greek, Roman, Early Christian and finally, modern Europe. He noted some variation in women's role over the course of Greek history, but on the whole women there were confined mainly to the household. The later corruption of morals in Greek social life was linked clearly for him to the weakening of its civilization. ${ }^{19}$. Women in the Roman Empire similarly suffered oppression by being seen primarily as sexual beings. Some relief in the consolidation of their position as powerful decision makers within the home came along with the advancing civilising strength of the Roman Empire. ${ }^{20}$ However, this fine balance was lost here too and society became licentious and pleasure loving. Women were transformed into objects of desire, and otherwise thoughtful philosophers such as Cato and Epictetus condoned youthful alliances and affairs. ${ }^{21}$

Christianity brought a higher moral standard to Europe. However, in their views about women these early Christians were, according to Maududi, "extremists" and "against human nature". ${ }^{22}$ They thought of women as the source of evil temptation, and as tools of Satan. Christian reformers saw physical relationships between men and women as impure and sinful, even among those in lawful marriages. Maududi saw this as a deepening of the neo-platonic (ashraqi falsafa) philosophical trends in Europe through Christianity. This led to a situation where women lost all economic power to men and became their property, lost the ability to divorce their husbands, and remarriage became disfavoured. ${ }^{23}$ These are rights that, at least in principle, were never denied to women in Islam.

This distinction had become an important theme in Muslim modernist writings of the late nineteenth century as many of the rights that women had to fight for in Europe were already part of the Islamic jurisprudence. For instance Sayyid Ahmed Khan noted in his Aurton kay Huqooq (Rights of Women) written in I87I that "till date no civilised country has bestowed on women the rights Islam gave them". He supported this claim by pointing out that in contrast to England where married women could not enter into any contract on their own - their property and possessions were under the control of their husbands such that they could not buy anything without their husband's permission-in Islamic law a woman could choose her spouse, own property, sign a contract with a man, and buy, sell, gift or endow her property as she wished. ${ }^{24}$

${ }^{18}$ Maududi, Pardah, p. I I.

${ }^{19}$ Ibid., pp. I4-I7.

${ }^{20}$ Ibid., pp. I7-20.

${ }^{21}$ Ibid., p. I9.

${ }^{22}$ Ibid., p. 20 .

${ }^{23}$ Ibid., pp. $2 \mathrm{I}-22$.

${ }^{24}$ Quoted in Asiya Alam, 'Polygyny, Family and sharaft: Discourses among North Indian Muslims circa I870I9I 8', Modern Asian Studies 45, 3 (201 I), p. 640. 
Maududi writes approvingly of the eighteenth-century European philosophers and activists who raised their voice in support of the rights of the individual in the face of such social oppression. He appreciates the succour these moves brought to "the human spirit" in "a civilisation that was borne of the unfortunate alliance between Christian ethics/philosophy and the system of Feudalism, ... and which conscripted the human spirit in entirely unnatural chains and closed all doors to progress". ${ }^{25}$ This was a welcome move, allowing women more freedom in their economic, social and personal lives, and yielded positive collective benefits. However, he saw a worrying trend that also began to shape these debates through the nineteenth century and came together with the strengthening of capitalism.

Maududi was thus deeply concerned with the meaning of equality (mussawat) that began to emerge in Europe with the entrenchment of capitalism. His worry was that ideas about equality and freedom moved in an extreme reaction to the comprehensive repression faced in Europe, far beyond a point of balance/justice (nuqta-e- 'adl). He reminded his readers that notions of equality that developed in Europe were an eruption against immensely repressive regimes of governance. ${ }^{26}$ The desire to sweep away all vestiges of the past, particularly during and after the French Revolution in I789, he felt, had led many to confuse freedom with the absence of a moral code, ${ }^{27}$ and equality with homogeneity. ${ }^{28}$ In fact, he said, Europeans are only able to respect women when they have been transformed into men (aurton ko mard bana kar izzat dī hai). ${ }^{29}$

These ideas were deeply entwined with the Industrial Revolution, which provided the scaffolding for further marketisation of women and men as exchangeable entities. While the capitalist system created many new products and means, the distributions of means for obtaining the many necessities of life was uneven. The "idea of individual freedom upon which capitalist system had been built was furthered through mass production" 30 as the establishment of factories fuelled the expansion of cities through mass migration. In the city, these migrants had to rely on the market for all basic necessities of life, and this increased pressures for every person in the family to earn a wage. ${ }^{31}$ These pressures had produced a situation wherein monetary worth defines the value of all work, and the unpaid labour that women undertake seems lowly within this framework. The "market" (bazār) now supplies what had been provided by women's labour within the family in the past. ${ }^{32}$

When the negative effects of these transformations in the organisation of the family and in the breakdown of a moral code became apparent, people were told that this is not "a fall, but emancipation [in English in the text, translated as uthān by Maududi], not amorality but the

${ }^{25}$ Maududi, Pardah, p. 23

${ }^{26}$ Ibid., p. 44 .

${ }^{27}$ One important source that he employed to trace the attenuation of a moral code was literature. George Sand the novelist, was for him an important manifestation of this trend both in her life and in her writing in the nineteenth century, promoting what he saw as both a lack of fidelity in relationships and enslavement to sexual whims (ibid, pp. 43-47).

${ }^{28}$ For instance, ibid., p. 24.

${ }^{29}$ Ibid., p. 2 I 7.

${ }^{30}$ Ibid., p. 57. Maududi used the English term "mass production" in his sentence as well as the Urdu transliteration "kaseer paidawari".

${ }^{31}$ Ibid., p. 58.

${ }^{32}$ Ibid., p. 25 . 
joy of life, and the pit that the capitalists are throwing you in, is not hell but heaven!". ${ }^{33}$ Maududi argued that women became particularly vulnerable in this context. Not only were their bodies used to sell merchandise, they themselves became products that were traded in international trafficking rings. ${ }^{34}$ Turned into underpaid labourers and commodities in international prostitution rings as well as avid customers of mass produced goods, particularly those promising to enhance their beauty, these women were increasingly unable to recognise their own worth.

Thus, the idea of social equality as practiced in Europe was, for Maududi, deeply imbricated with marketisation. He argued forcefully against the idea that the spiritual equality of all believers, men and women, that the Quran proclaims, could translate into this kind of social equality. Instead, he believed social equality to be ultimately impossible because dominant ideas of social equality seemed to confuse homogeneity with equality. Men and women have equal worth and equivalent capabilities; they are, he claimed using the English term, "equipotential". ${ }^{35}$ Both had similar needs and similar capacities, so it was entirely right that there be legal and political equality between the two; nations that had "denied equality to women and kept them illiterate, uneducated, oppressed and without citizenship rights, ultimately perished themselves because degrading half of humanity means degrading the whole of it". ${ }^{36}$ Yet, this equality did not mean that "nature had intended for each to do the same as the other" and that they had to carry out the same responsibilities in each area of life. ${ }^{37}$ There were particular spheres within which each shone, and for women, Maududi thought, this was the home.

Maududi's incorporation of a Marxist reading of European history, linking societal transformations and ideational changes, capitalist transformation of social relations, marketisation of labour, and the abjection of wage labourers, is evident from the above account. It is known that Maududi explored the works of Marx, Hegel, Comte, Hobbes and other European philosophers in English and in Urdu translations. His engagement with Marx's own writings seems to have been limited, however. What he responded to primarily was the wide circulation of Marxist ideas in urban colonial India. Hence, he elaborated a layered critique of Marxist thought that I shall discuss in the next section. At this point, however, it is useful to note that notwithstanding his critique of Marx and Hegel, Maududi found much of value in Marx. He seems to have considered Marx more useful as a historian than a philosopher. ${ }^{38}$ Marx, he thought, provided a good insight into the transformations in European society, but had limited understanding of humanity in its diversity and misunderstood completely the fundamental battles of human life. Again I shall turn to these in more detail in the next sections.

\footnotetext{
${ }^{33}$ Ibid., p. 58.

${ }^{34}$ Ibid., pp. 59-6I,

${ }^{35}$ Ibid., p. I 55 .

${ }^{36}$ Ibid.

${ }^{37}$ Ibid., pp. I $55^{-1} 56$.

${ }^{38}$ Others such as Nehru also seem to have primarily appreciated Marx's historical analysis and used it for nonMarxist ends, but did engage more deeply with Marx's ideas (Sanjay Seth, “Nehruvian Socialism”: I927-I937: Nationalism, Marxism, and the Pursuit of Modernity', Alternatives I 8 (I993), pp. 453-473). Nehru, for instance, took Marxism as economic determinism and characterised Marxism as essentially "certain scientific methods of trying to understand history, trying to understand from past events the laws that govern the development of human society...." (p. 463).
} 
It is useful to note that while Maududi was a parochialiser of Marxist theory, he was also deeply inspired by the success of the Marxist and Socialist movements around the world. In a I936 article he wrote against the idea that dramatic and foundational changes in society could not be brought about within a lifetime, presenting first the Prophet Mohammed as a great revolutionary ${ }^{39}$ and then pointing towards the communist movement as a recent example:

In the nineteenth century capitalist imposition had reached its apogee. Nobody could have predicted that the system that controls the whole world...can be overturned. But in these conditions a man named Karl Marx started proselytising for communism. He was thrown out of his home, had to move from country to country and lived like a pauper. However, before he died he was able to make a strong party of communists that not only took over Russia within 40 years...but shook the capitalist system to its roots... ${ }^{40}$

Indeed, it would have been hard for Maududi to have ignored the enthusiasm for Marxist and socialist ideas in the political context of early-twentieth century colonial India. Indian scholars and activists had started engaging with Marxist and socialist ideas from the late nineteenth century. One important contribution that Maududi is likely to have read was the I9I2 English language publication by Mushir Husain Kidwai, Islam and Socialism. Kidwai insisted that principles of equal dignity and shared living that Europeans had elaborated through socialism were Islamic ideas that could be traced through Islamic history and Quranic texts. ${ }^{41}$ The centrality of equality in Islam was a consistent theme among many Muslim communists and socialists. ${ }^{42}$ More interestingly, articulating an idea on which Maududi was to build systematically, Kidwai pointed towards the importance of shari'a or "divine laws" as an important element establishing the superiority of the Islamic system:

Socialists of the present day aspire only to democratic Socialism. They want to introduce government by delegation to municipalities or to a representative body. But government by delegation or representation is democratic and not Socialistic in its true sense. Under a Socialistic system the people themselves ought to have a direct voice in the State. The Muslim State reached the zenith of Socialism in this respect. People knew that the legislature was not in the hands of any Cabinet or Parliament. It could never be partial to the interests of any class or sex or constituency. ... As far as the interpretation of the Divine law of Musalmans was concerned, Islam gave universal franchise to men and women both. Islamic laws could sometimes be better interpreted by a poor old woman than by the Khalifa, and the Khalifa in that case had to follow the lead. ${ }^{43}$

\footnotetext{
${ }^{39}$ Maududi retained his enthusiasm for revolutionary change. See Fuchs in this volume for his support for the Iranian revolution. For the sociological permeability between Marxist and Islamist parties in Iraq, see Scharbrodt in this volume.

${ }^{40}$ Maududi, 'Kaish mardan na kay mazhab go safandan', Tarjuman-ul-Quran (April I936), reprinted in Tanfihat: Mashriq aur Maghrib ki Tehzibi Kashmakash par fik angaiz maqalat (Lahore, 2016), p. 209.

${ }^{41}$ For instance, laying out the main claim of his book, he said, "the idea of Socialism in Islam is not less than thirteen centuries old and cannot be attributed to European influence. I do not mean to say that any organised Socialistic propaganda existed then as it does now, but I may safely assert that the principles of Socialism were not unknown to the Muslim society of the time of Muhammad himself, and that in many respects those principles were made more adaptable then than at any time afterwards in Europe". S. M. H. Kidwai, Islam and Socialism (London, I9I2), p. 4 .

${ }^{42}$ See, for instance, D'Souza, Conceptual World of Ghaddarites, pp. 23-24, and K. H. Ansari, 'Pan-Islam and the making of the early Indian Muslim socialists', Modern Asian Studies 20, 3 (July I986), pp. 5I9, 530.

${ }^{43}$ Ibid.
} 
Kidwai's ideas and his vision of pan-Islamic resistance to colonial rule was immensely influential particularly in South East Asia, ${ }^{44}$ and he was an energetic political activist moving across Middle East, Asia and Europe. Maududi had participated in initial debates about one such agitation that became known as the Hijrat Movement, led by a group of Muslims who decided to leave India after the failure of Khilafat Movement, the joint Hindu-Muslim mobilisation to save the Ottoman Caliphate from dismemberment by Britain after the First World War. ${ }^{45}$ Some of these Muslim leaders ended up in the Soviet Union and were among India's first communists. ${ }^{46}$ Muslim leftists led the Progressive Writers Movement, and many of them belonged to the same social milieu as Maududi. Indeed, he had attended meetings held by the Khairi brothers in Delhi between I929-3 I where socialist ideas were discussed and debated. ${ }^{47}$

More importantly, through the I920s communism had gained visibility and importance in Indian national life. A series of conspiracy cases against communists in Peshawar (including Muslim communists returned from the University of Easter Toilers in USSR), Kanpur and Meerut had the paradoxical effect of establishing the seriousness of communism as a threat to the British Empire. ${ }^{48}$ The popularity of youth leaders such as Bhaghat Singh ${ }^{49}$ together with that of the Ghadar party helped further a religiously inspired, vernacular Marxist critique of British imperialism. By the I930s the Indian National Congress, the main nationalist party, despite Gandhi's resistance, had moved left due to various internal and external pressures. ${ }^{50}$ The anti-colonial movement had taken on a distinctly red hue; Marxism had become the main language of anti-colonial activism.

It is perhaps more accurate to state that Marxism and socialism furnished a language that accorded well with longstanding ideas about ruler accountability and subversive equality in South Asia through a range of influences including Sufi thought, ${ }^{51}$ and allowed South Asian socialists to retain a strong religious element in their thought. Similarly, Dalit and other caste critics had long organised against caste oppression and found Marxist ideas amenable to their concerns. Anupama Rao contends that "Marxism took up and redefined extant practices of anti-caste critique-e.g. the concern with historic dispossession, the focus on dignity and respect, and the demand to value work and labour. In the process, Marxist thought was rendered both more capacious and more specific". ${ }^{2}$ That is to say, opposition to dispossession

\footnotetext{
${ }^{44}$ Kevin Fogg, 'Indonesian Islamic Socialism and its South Asian roots', Modern Asian Studies 53, 6 (20I9), pp. I736-I76I.

${ }^{45}$ Maududi moved away from the movement after disputes with its leaders, apparently because of his insistence that the strategies and goals be planned and realistic. See Khurshid Ahmed and Zafar Ishaq Ansari (eds.), Islamic perspectives: Studies in the honour of Maulana Sayyid Abul A'la Mawdudi (Leicester, I979), p. 36I.

${ }^{46}$ Ansari, 'Pan-Islam', pp. 509-537.

${ }^{47}$ K. K. Aziz, The Idea of Pakistan (Lahore, I987), pp. 88-92.

${ }^{48}$ Ali Raza, "Separating the Wheat from the Chaff: Meerut and the Creation of "Official" Communism in India', Comparative Studies of South Asia, Africa and the Middle East 33, 3 (2013), pp. 316-330.

${ }^{49}$ Sumit Sarkar, Modern India 1885-1947 (New Delhi, I983), pp. 268-270.

${ }^{50}$ Jayabrata Sarkar, 'Hegemony and Politics: Leadership Struggle in Congress in the I930s', Modern Asian Studies 4O, 2 (May 2006), pp. 333-370. This did not, however, lead to the dominance of Marxist parties. If anything, Nehru's socialism expressed through the Indian National Congress party seems to have had a detrimental impact on Indian Marxist parties (Seth, Nehruvian Socialism).

${ }^{51}$ D'Souza, Conceptual world of the Ghaddarites, pp. I8-20, 29.

${ }^{52}$ Anupama Rao, 'Ramchandra Babaji More and the Itineraries of Dalit Modernity', in Satyendra More, Memoirs of a Dalit Communist: R. B. More; The many worlds of a Dalit communist, (edited and introduced by) Anupama Rao (translated by) Wandana Sonalkar (Delhi, 20I9), p. 46. Some of this richness of debates was not reflected in the
} 
and the demand for dignity had existed prior to the exposure to Marxism. These activists and thinkers reworked Marxist ideas to include caste as a fundamental contradiction and to expand the idea of equality in multiple ways. It was in this intellectually and politically rich milieu that Maududi found much of value in Marxist thought while remaining unconvinced of some basic assumptions made and solutions proposed by Marxists around him.

\section{Nuqta-e-'Adl: Balancing Individual and Collective Rights}

As the twentieth century progressed Maududi became increasingly concerned with the widening fervour for popular sovereignty as a consequence of anti-colonial activism across the political spectrum. He believed that the idea of popular sovereignty played a double trick on humans. The misconception that they are equal in all respects allows each to think she can decide her own moral code while majoritarian decision-making means that there can be no consistency in any moral framework. There are no clear metrics of right and wrong. This bewildering freefall into what he regarded as moral decay could not be halted through laws and courts. Laws of state could be changed under pressure from a majority, and courts reorganised. In any case, many fundamental questions were outside the domain of the courts. Initially drawn into this question because of his concerns about the scope for oppression of minorities within such amoral majoritarianism, Maududi came to see popular sovereignty as a moral problem. ${ }^{53}$ Divine sovereignty, or acceptance of the idea that there is a higher being who has laid down a clear moral framework for humans to interpret at each historical epoch according to its needs, was for him the solution to this individual and collective moral crisis.

It was in this context that, for Maududi, this drive towards social equality posited a profound threat to collective life. Capitalism had already weakened the bonds of familial relationships as those without an income were seen as burdensome by their family members. ${ }^{54}$ He argued that within this framework if a woman stepped out to earn a living for herself, it would not be surprising that she should ask why she had to carry the burden of a family with her. In particular, if social equality is the ethical norm to guide our lives, then there is no reason why anyone would give up their own desires and aspirations to take up the burden of responsibility for a collective. Precise calibrations of who did what for whom at what time would destroy the spirit of mutual respect for each other's different roles that Maududi envisioned existing within an ideal family. For him social equality understood as sameness fundamentally destabilised the collective. Any collective enterprise, he argued, operates on the trust that every person who benefits from it will also contribute, in whatever capacity, towards its maintenance and continuation. The relationship between the individual and the collective required a fine balance of individual fulfilment and collective responsibilities. He recognised

how difficult it is to obtain and sustain the point of justice (nuqta-e-'adl) on the question of women. This point of justice has to be that on the one hand a woman is able to develop her

theoretical works being carried out by upper class communists at a later stage. See Sudipta Kaviraj, 'Marxism in Translation: Critical Reflections on Indian Radical Thought', in Political Judgement: Essays for John Dunn, (eds.) Richard Bourke and Raymond Geuss (Cambridge, 2009), pp. I72-200.

${ }^{53}$ See Iqtidar, 'Theorising popular sovereignty'.

${ }^{54}$ Maududi, Pardah, pp. 57-58. 
personality and her abilities to their fullest, and that she is able to participate in the development of human civilisation with well-honed abilities, but on the other hand she does not become a means to moral degradation and a tool of human destruction. ${ }^{55}$

As far as Maududi was concerned capitalism had failed miserably to provide that point of balance where the rights of the individual are met along with the demands of the community. While there was less empirical evidence for communist states at that time, Maududi rallied what he could from the experience of the Soviet Union ${ }^{56}$ but relied essentially on a philosophical critique of communism to argue that it denied the individual agency that was central to Islamic conception of the self. Both communism and capitalism, he argued, were incapable of providing that point of perfect balance (nuqta-e- 'adl) in general, as well as specifically in the case of women. In a range of writings and not just in Pardah, Maududi argued that communism and capitalism (or what we might call Liberalism today) were "extremist" philosophies, and that he was instead looking for a middle ground. ${ }^{57}$

Marxism by late I930s was, of course, not the same thing as Marx's social philosophy. For one, the tensions that had added richness to Marx's thought had been largely ironed out by later interpreters to present Marxism as a science of historical development, and in India as integral to national liberation. ${ }^{58}$ Maududi's direct engagement with Marx's writings also seems limited. He did, however, read at least some of Marx's work although it is not clear what exactly, and in I939 he produced an essay evaluating the philosophical approach of Hegel and Marx. ${ }^{59}$ While admitting that there was much to appreciate in their thought and that they elaborated "one aspect/element (juz') of reality", ${ }^{60}$ Maududi was sceptical about their understanding of the world beyond Europe. He had two major critiques. The first related to the lack of human agency in the thought of Hegel and Marx. Maududi thought that Hegel in particular presented the idea that a human being has no "independent consciousness, control, and will"; ${ }^{61}$ this was not something that he thought an Islamic view of the self could condone. Moreover, he found Hegel's view of history to rest on speculation rather than historical detail; instead of detailed analysis of the process through which the dialectical process (jadli 'amal) takes place, Hegel "looks at it as if a bird flying in the air looks over the whole city". ${ }^{62}$ Marx, he thought intensified the lack of individual autonomy ( $k$ hud ikhtiyari) that Hegel proposed by relying heavily on the idea of the material, reducing human beings to biological rather than spiritual beings.

Like Marx, Maududi also saw human history as manifesting a profound struggle. But in contrast to Marx, for him this struggle was between the different aspects of human nature, the base elements and the spiritual self. As the most natural (fitri) vision of human life, ${ }^{63}$ he

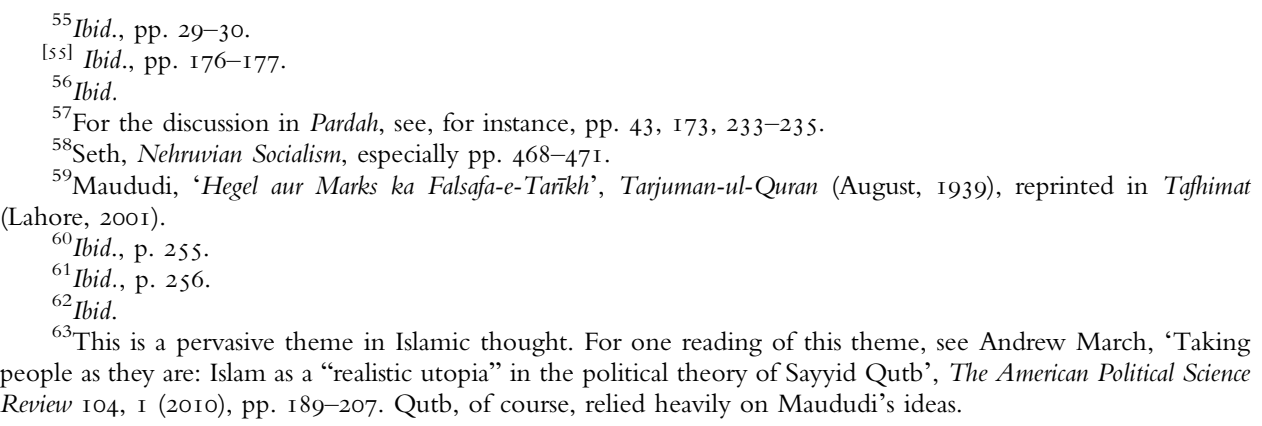


thought Islam had already acknowledged both these aspects and catered for them by recognising that while each individual was responsible for struggle with her own nafs (self/soul), ${ }^{64}$ society could and should provide support to her. This led to a profound difference with Marxian understandings of society. Drawing upon a well-established and dominant thrust in Islamic thought, ${ }^{65}$ Maududi saw social harmony as always within reach of a society, both an important goal and a means of establishing shari ' $a$. The individual was not in tension with the community, nor were the different segments in zero sum competition with each other. There was, then, a fundamental difference between the Marxist conception of society as being comprised of classes with irreconcilable differences, and Maududi's vision of society as the means to individual ethical perfection. Society was not perfect and needed periodic reforms to respond to historical needs, hence his own efforts, but he did not see how pitting different classes and groups against each other could help resolve the problems that Marxists identified.

This also had implications for his disregard for the battle between the individual and community that much liberal thought assumed. The idea of the individual is not a European invention despite the claims of some recent scholarship. ${ }^{66}$ Maududi seems to have sought to distinguish between the idea of the individual and individualism. The importance and centrality of the individual will is well established through the idea of the individual agency and intention in Islamic thought. The Islamic notion in commonly-cited ahadith (sayings of the Prophet) that each individual is responsible for her actions, and that actions are to be judged according to each individual's intention (innama' 'l-a 'māl bi'l-niy yāt), gave him grounds to argue that human agency is central to Islam. Individualism, on the other hand, was, he suggested, a European philosophy and linked profoundly to the moral crisis that he saw in Europe.

The key conclusion for Maududi was that individualism placed the individual and community in opposition to each other. While communism posits a foundational contradiction between the working class and the bourgeoisie, liberal thought (or ideas that he associated with capitalism) is particularly conflicted about the relationship between the individual and the community. There is a concern that communities may oppress individuals but the state that is needed to protect individuals may itself oppress both individuals and communities. At the root of this concern is the anxiety that communities can usurp the freedom of individuals. In as much as liberalism is about individual liberty and equality within a polity, there is no easy way to allocate normative precedence to either freedom or equality. Maududi reconfigured this conundrum by insisting that relationship between community and individual need not be as conflict ridden as the European experience had primed European thinkers to believe.

Hence, he recast the relationship as one of individual obligation towards the community stating that "If we understand well the place of the individual in collective life then there can

\footnotetext{
${ }^{64}$ See Nafs, Encyclopedia of Islam, available at https://referenceworks.brillonline.com/entries/encyclopaediaof-islam-2/nafs-COM_0833 (accessed 24 April 2020).

${ }^{65}$ One very helpful elaboration of the dominant understanding of the relationship between the individual and community in Islamic thought and practice is by Wael Hallaq in The Impossible State: Islam, Politics and Modernity's Moral Predicament (New York, 20I3), pp. I I8-I38.

${ }^{66}$ Larry Sidentop, Inventing the Individual; The Origins of Western Liberalism (London, 2014). However, Sidentop does not draw any distinction between individualism and the idea of the individual.
} 
be no doubt that all the potential that has been granted to us is not just for own use but in trust for the whole of humanity". ${ }^{67}$ All individuals had a role to play in society and those roles could not be readily exchanged. There were, he implied, particular and specific responsibilities or obligations that the focus on equal rights seemed to obscure. Women carried the obligation of ensuring that a sound community of believers was reproduced by fulfilling, to the best of individual abilities, roles that they alone were biologically equipped to carry out. ${ }^{68}$ If a woman placed individual freedom over communal responsibility, she was a "traitor to the collective" ${ }^{99}$ while also paradoxically surrendering to social homogenisation because raising children was akin to art, and not like churning out shoes from a "Bata factory". 70

Maududi's methodical elaboration of the specific problems with the demands for women's equality is relatively unique in its reliance on biological arguments similar to the European writers he drew upon, even though in placing the burden of maintaining the community on women Maududi was not alone among anti-colonial or nationalist thinkers and reformers across religious communities, Hindu and Muslim, in South Asia. ${ }^{71}$ As Sanjay Seth has shown in his comparison of the "woman question" in India and China, while direct and indirect colonial control had some role to play in the differences between the two, much more significant were how colonialism figured in anti-colonial thought. ${ }^{72}$ One important feature of colonial control in India had been the discursive importance of the alleged backwardness of women in India in providing a rationale for the civilising imperial rule. Anti-colonial thinkers of various intellectual persuasions came to locate control over their culture and nation through women. The separation of the home as the domain of authenticity, then required women to become responsible for the continuation and safety of the native core. ${ }^{73}$ However, as Tanika Sarkar has argued, the roles proposed cannot be seen as those traditionally played by women in these contexts, nor were the norms of domesticity imposed by reformers uncontested within the traditional frame. In the case of Bengal, for

\footnotetext{
${ }^{67}$ Maududi, Pardah, p. I 37.

${ }^{68}$ Maududi relied heavily on reports by European and Russian biologists, doctors and psychiatrists to establish the biological differences between men and women that meant that women were unsuited to work outside the home (Ibid., pp. I56-I65). These included the impact of menstrual cycles, hormonal changes, and pregnancy on women's abilities to concentrate as well as sustain physical exertion. He quoted, for instance, Dr Emile Novak, an American gynecologist whose textbook became the standard for mid-century teaching in departments of medicine, Dr Kraft Ebbing, a German psychiatrist, and the Russian Dr V. Reprev, in order to make his claims about definitive biological differences between men and women that mandate different social roles for them.

${ }^{69}$ Ibid., p. I 33 .

${ }^{70}$ Ibid., pp. I42-143.

${ }^{71}$ Tanika Sarkar, Hindu Wife, Hindu Nation: Community, Religion and Cultural Nationalism (New Delhi, 200I); Partha Chatterjee, The Nation and Its Fragments (Delhi, I995); Faisal Devji, 'Gender and the politics of space: The movement for women's reform in Muslim India, I857-I900', South Asia: Journal of South Asian Studies I4, I (I99I), pp. I4I-I 53; Alam, Polygyny, family and sharafat, pp. 63 I-668.

${ }^{72}$ Sanjay Seth, 'Nationalism, Modernity, and the "Woman Question" in India and China', The Journal of Asian Studies 72, 2 (2013), pp. 273-297.

${ }^{73}$ This view was held even by 'progressives'. For instance, Munshi Premchand, one of the greatest of modern Urdu/Hindi writers and a member of the left-leaning Progressive Writers Association, articulated deep anxieties about the westernised Indian woman who forgets her role in maintaining social harmony and local tradition. As Seth notes (Gender and the Nation, p. I43) in relation to one of Premchand's short stories, Shanti (I920), "a western-educated husband encourages his wife to become modern and western, with disastrous results for the happiness of the husband and the well-being of the joint family. The husband eventually declares, 'I want to again see you as a woman who is shy, walks with her head down, reads Ramayan, does household work, spins charkha, is scared of god and is completely devoted to her husband'. The wife complies, and order and happiness are restored to the household".
} 
instance, Sarkar has noted the existence of an old and deeply influential counter-tradition of folklore that described marriage and domesticity as a source of profound unhappiness for women. $^{74}$

Interestingly, the precise norms of segregation and veiling that Maududi proposed were not a sociological reality even around him, including within his own family. ${ }^{75}$ The norms of gender segregation that he offered were alien to vast segments of Muslims even in his native North India. More critically, the rationale for these norms departed dramatically from more traditional explanations for gender segregation and differentiated roles for men and women. Faisal Devji has noted perceptively that with the emergence of the woman as "an abstract Muslim individual... she was to be distinguished from men non-culturally and non-psychologically for the first time: her uniqueness now very frequently resting on European-derived notions of absolute sexual difference". ${ }^{76}$ Maududi proposed a rigid biological framework for thinking about women's role in society. This was a dramatic shift from how the difference between men and women had been conceptualised in the past. Biological differences between men and women had been known, debated and explored in Islamic contexts for a variety of reasons, ${ }^{77}$ but Maududi brought a new emphasis on women's insurmountable weaknesses. Assessing the call for social equality to be fundamentally connected to the marketisation of society and therefore conceptualised as exchangeability, Maududi sought to utilise modern scientific and biological data to halt this erosion of moral limits facilitated by popular sovereignty. This biological reasoning placed women within a much more restrictive framework than ever before.

\section{Conclusion}

In his thoughtful analysis of conservatism Richard Bourke has looked into how we might work through critical reconstruction of political thought for "practical dividends by challenging counter-productive assessments". ${ }^{78}$ In his appraisal of Burke's alleged conservatism, Bourke suggests that instead of "despairing" at the thought of particular norms and their advocates "we would be better off trying to understand how for Hume, Smith, Montesquieu, Rousseau, Hegel and Burke alike, the idea of conforming the mode of government to an established system of ranks (emphasis added) could have seemed like a recipe for peace and prosperity". ${ }^{79}$ There are two important insights here upon which I want to draw. First, to engage in critical but rigorous philosophical reconstruction of ideas, however alien to our own inclinations, is important for understanding our own commitments better. To recover a critique of social equality is not to give up on the ideal, but to think through its limitations and potential more clearly.

Second, and relatedly, as Bourke mentions, the particular question of equality and its relationship to democratic governance and social harmony bears further questioning. What

\footnotetext{
${ }^{74}$ Sarkar, Hindu Wife, Hindu Nation, p. 44.

${ }^{75}$ Maududi's wife Begum Mahmudah did not follow all of his recommendations either, and continued live without pardah as late as the I96os. See Nasr, Making of Islamic Revivalism, p. I 52, fn. 49.

${ }^{76}$ Devji, 'Gender and Politics of Space', p. I 52. I983).

${ }^{77}$ See, for instance, Basim Musallam, Sex and society in Islam: Birth control before the nineteenth century (New York,

${ }^{78}$ Richard Bourke, 'What is conservatism', p. 452.

${ }^{79}$ Ibid., p. 470.
} 
precisely is equality for? Is it an end in itself? Is to support dignity or some other more fundamental value $?^{80}$ Or is it ultimately the best way to ensure liberty? ${ }^{81}$ In the latter cases, equality is of significance because of its contribution to some other end. A close reading of Maududi's ideas raises other questions for us to consider. For instance, might it be useful to consider spiritual, legal and social equality as related but distinct commitments? Accordingly then, would it make sense to elaborate their independent implications for our desired end, be it justice or liberty? What are the consequences of thinking about gender social equality as exchangeability between men and women? Ultimately, the purpose is not philosophical hairsplitting but a better understanding of the cherished ethical norms and political values with an eye to their practical implications and consequences.

Maududi's critique of social equality between men and women was predicated on opposition to taking European norms as universally applicable, concerns about a homogenising modernity where humans could be treated as exchangeable factors of production, and adherence to a vision of society as the means to the ethical perfection of the individual. Questions about the substantive contours of equality and the implications of individualism have also been raised by feminist scholars from the global south and elsewhere. ${ }^{82}$ For instance, the contemporary African American feminist scholar and activist bell hooks has critiqued white middle class feminists for projecting their demands as universal ones, and in the specific context of family argued that the

devaluation of family life in feminist discussion often reflects the class nature of the movement. Individuals from privileged classes rely on a number of institutional and social structures to affirm and protect their interests. The bourgeois woman can repudiate family without believing that by so doing she relinquishes the possibility of relationship, care, protection. If all else fails, she can buy care. ${ }^{83}$

Here hooks is not repudiating the ideal of women's equality but suggesting that what exactly that liberation and equality look like would be context dependent. The hyper-individualism and marketisation of women's labour within capitalist structures continues to be of concern to many feminists. 84

These feminist scholars have however, continued to find inspiration in Marxist ideas for the resolution of these problems. Maududi, on the other hand, saw Marx as an insightful historian who provided a good overview of some of the major changes that Europe had undergone in the previous century. For inspiration for solutions to the problems identified by Marxists and accepted as such by Maududi, he turned once again to his notion of hakimiyyat as providing a moral framework for all aspects of life. Man-made laws could never carry the same legitimacy but, more importantly, never fully balance the demands of

\footnotetext{
${ }^{80}$ This is one of the arguments made by the philosopher T. M. Scanlon, who is skeptical of the ethical value of equality in itself, in Why does inequality matter? (Oxford, 2018).

${ }^{81}$ Elizabeth Andersen, 'What is the point of equality?', Ethics Io, 2 (I999), pp. 287-337.

${ }^{82}$ Saba Mahmood, Politics of Piety: The Islamic Revival and the Feminist Subject (Princeton, 2004); Chandra Talpade Mohanty, Under Western Eyes: Feminist Scholarship and Colonial Discourses, Feminist Review 30 (I988), pp. $6 \mathrm{I}-88$.

${ }^{83}$ Bell Hooks, Feminist theory from margin to the centre (Boston, I984), p. 37.

${ }^{84}$ For a forceful and articulate recent commentary, see Cinzia Azzura, Tithi Bhattacharya and Nancy Fraser, Feminism For the 99\% (New York, 2019).
} 
community and individual, men and women, because human insight is invariably limited. Humans are limited in their attempts at the arrogation of Allah's right to legislate by their inability to understand themselves as well as the lives of others. Recognising the sovereignty of Allah entailed accepting the framework for morality that came with the Quran. The Quran, Maududi thought, mandated spiritual, political and legal equality, empathy with others, reduction of difference between rich and poor, humility and modesty but not social equality in the sense of homogenisation and the exchangeability of roles. ${ }^{85}$ An end to gender segregation, he argued, would ultimately lead to such homogenisation of roles.

As with his reading of Allah's political sovereignty, Maududi's interpretation of Quranic sources regarding women's role in social life remains controversial for many Muslims. Nevertheless, there is an important claim at the heart of his vision of hakimiyyat and that is the essential equality among humans, meaning that none has the right to oppress the other and all are subordinate to the will of the divine. The tensions in his thought between explicitly accepting the spiritual, legal and political equality of women as well as their "equipotentiality' while also insisting on an unequal division of authority with men and differentiation of their social roles, has produced complex results. His ideas and the Jama'at-e-Islami (JI), the party he founded, have been influential in reinforcing norms of gender segregation and veiling. At the same time, in combination with factors such as demographic changes and increased literacy rates, these tensions have provided openings that have meant that women in the JI have come to play an important role within and through the party. Indeed, the JI has over time emerged as a platform for the training of women leaders in ways unforeseen, and very likely disapproved by Maududi. These women have used arguments about their spiritual equality in Maududi's writings to argue for greater responsibility and involvement in political mobilisations and social institutions. ${ }^{86}$ Maududi's legacy in this as in other aspects of his thought has had many unintended and unexpected consequences.

Humeira IQTidar Kings College, University of London humeira.iqtidar@kcl.ac.uk

\footnotetext{
${ }^{85}$ In terms of economic equality, Maududi opposed left-inspired calls for land redistribution, arguing that private property was not outlawed in Islam. But when forced by the political strength of such demands in post-colonial Pakistan, he supported a limit on land holdings, arguing that extreme inequality is also not allowed in Islam.

${ }^{86}$ See Amina Jamal, Jama'at-e-Islami women in Pakistan: Vanguard of new modernity? (Syracuse, 20I3); Humeira Iqtidar, 'Women in the JI: Harbingers of Change?', in Iqtidar, Secularizing Islamists?, pp. I29-154; Elora Shehabuddin. 'Jamaat-i-Islami in Bangladesh: Women, Democracy and the Transformation of Islamist Politics', Modern Asian Studies 42, 2-3 (2008), pp. 577-603.
} 